\title{
Hyperactivity of Neutrophil Leukotactic Responses during Active Bacterial Infection
}

\author{
Harry R. Hill, Jonathan M. Gerrard, Nancy A. Hogan, and Paul G. Quie \\ From the Department of Pediatrics, University of Minnesota Medical School, \\ Minneapolis, Minnesota 55455
}

\begin{abstract}
A в S T R A C T To determine if changes in neutrophil leukocyte function occur during active bacterial infection, the neutrophils of 25 patients with active bacterial infection and 25 age-matched controls were compared for leukotactic activity, random mobility, and nitroblue tetrazolium reduction. The neutrophil leukocytes of patients with bacterial infection were hyperactive in unidirectional movement toward a chemotactic stimulus as measured in the leukotactic assay and usually had increased nitroblue tetrazolium reduction. The mean leukotactic index was $165 \pm 56$ in patients with bacterial infection and $70 \pm 11$ in controls $(P<0.001)$. After 7-10 days of appropriate therapy with clinical and bacteriological response, leukotactic activity returned to normal values. A hyperactive leukotactic response continued, however, in patients with persisting bacterial infection. The hyperactive leukotactic response of circulating neutrophils appears to be an early and sensitive event in the inflammatory cycle stimulated by bacterial infection and may aid in the localization of invading bacteria.
\end{abstract}

\section{INTRODUCTION}

The initial inflammatory response to bacterial invasion of the body is critical as a determinant of the outcome of infection. Animal studies have demonstrated that prompt infiltration of phagocytic cells into an area of bacterial invasion is essential if multiplication of the organism is to be suppressed and generalized infection prevented (1). Leukotaxis, unidirectional movement of leukocytes toward a chemotactic stimulus, is considered to be one of the mechanisms by which phagocytic cells are attracted to an area of bacterial invasion.

This study was presented in part at the Meetings of the Society for Pediatric Research, San Francisco, Calif., May 1973.

Received for publication 12 September 1973 and in revised form 26 November 1973.
Functional leukotactic defects have been described in patients during active bacterial infection. McCall, Caves, Cooper, and DeChatelet (2) found depressed phagocytic, bactericidal, and leukotactic activity in "toxic" neutrophils from patients with severe infection. Mowat and Baum (3) have reported a cellular leukotactic defect in patients during bacterial infection. In contrast, Perille, Nolan, and Finch (4) found an increased accumulation of neutrophils at the site of skin abrasion in patients with bacterial infection. The present investigations were undertaken to determine the functional capabilities of the cellular and humoral components of the leukotactic mechanism during bacterial infection.

\section{METHODS}

\section{Patient selection}

The leukocyte function of 25 patients with clinical and laboratory evidence of bacterial infection were compared with those of 25 age-matched controls. The patients' ages ranged from $10 \mathrm{mo}$ to $60 \mathrm{yr}$ with a mean age of $11.5 \mathrm{yr}$. 10 patients were female and 15 were male. The type of infection and bacterial etiology are shown in Table I. In all but three cases, the etiologic agent was isolated directly from the site of infection or from the blood or urine. Diplococcus pneumoniae was cultured from the pharynx of these three patients each having elevated temperatures, high peripheral leukocyte counts, and lobar consolidation on $\mathrm{X}$ ray. All responded within $24 \mathrm{~h}$ to penicillin or ampicillin therapy and are felt to represent cases of pneumococcal pneumonia. The median duration of signs or symptoms of infection before leukocyte testing was 4 days with a range of $12 \mathrm{~h}-3 \mathrm{yr}$. Antibiotics had been administered to 12 of the patients before leukocyte function was studied, but none had been on appropriate therapy for more than $48 \mathrm{~h}$ before initial leukocyte testing.

Age-matched controls consisted of patients hospitalized for other than infectious illnesses, children in on-going epidemiological studies and laboratory personnel.

\section{Leukocyte function tests}

Leukotaxis. The in-vitro method used for studying leukotaxis was a modification of the procedures of Ward, 
TABLE I

Clinical and Bacteriological Data and Results of Leukocyte Function Tests in 25 Patients with Bacterial Infection

\begin{tabular}{|c|c|c|c|c|c|c|c|c|c|}
\hline Subject & Age & $\begin{array}{c}\text { Duration } \\
\text { of } \\
\text { disease }\end{array}$ & Diagnosis & Etiological agent & $\begin{array}{l}\text { NBT- } \\
\text { positive } \\
\text { PMN }\end{array}$ & $\begin{array}{l}\text { PMN } \times 10^{6} \\
\text { per ml } \\
\text { of LRP } \ddagger\end{array}$ & $\begin{array}{c}\text { PMN } \times 10^{5} \\
\text { delivered } \\
\text { to filter }\end{array}$ & $\begin{array}{l}\text { Leuko- } \\
\text { tactic } \\
\text { index }\end{array}$ & $\begin{array}{c}\mathrm{C} 3 \\
(\mathrm{BIC} / \mathrm{BIA}) \\
\text { concen- } \\
\text { tration }\end{array}$ \\
\hline & & & & & $\%$ & & & & $m g / 100 m l$ \\
\hline 1 & 4 & 2 days & Pneumonia & Staphylococcus aureus & 16 & 3.8 & 3.8 & 116 & 140 \\
\hline 2 & 60 & $2 \mathrm{yr}$ & Abscesses & Staphylococcus aureus & 11 & 10.1 & 10.1 & 101 & 140 \\
\hline 3 & 4 & $12 \mathrm{~h}$ & Meningitis* & Haemophilus influenzae & 21 & 28.1 & 14.0 & 146 & 140 \\
\hline 4 & 13 & 21 days & Cutaneous ulcer & Proteus mirabilis & 13 & 17.3 & 8.7 & 185 & 160 \\
\hline 5 & 15 & $2 \mathrm{yr}$ & Superficial abscess & Staphylococcus aureus & 12 & 17.7 & 8.9 & 169 & 145 \\
\hline 6 & 22 & $2 \mathrm{yr}$ & Osteomyelitis & Staphylococcus aureus & 13 & 13.1 & 13.1 & 153 & 165 \\
\hline 7 & 10 & $12 \mathrm{~h}$ & Meningitis* & Slaphylococcus aureus & 1 & 11.6 & 11.6 & 125 & 180 \\
\hline 8 & 22 & 6 days & Endocarditis* & Staphylococcus epidermidis & 1 & 40.3 & 10.1 & 110 & 140 \\
\hline 9 & 10 & $36 \mathrm{~h}$ & Pyelonephritis & Escherichia coli & 24 & 24.7 & 12.4 & 307 & 140 \\
\hline 10 & 2 & 6 days & Pneumonia* & Diplococcus pneumoniae & 32 & 25.3 & 12.7 & 190 & 140 \\
\hline 11 & 11 & 5 days & Orbital cellulitis & Staphylococcus aureus & 33 & 13.2 & 13.2 & 158 & 190 \\
\hline 12 & 5 & 2 days & Pneumonia & Diplococcus pneumoniae & 46 & 22.7 & 11.4 & 173 & 200 \\
\hline 13 & 1 & 4 days & Pneumonia & Diplococcus pneumoniae & 50 & 15.5 & 15.5 & 190 & 125 \\
\hline 14 & 4 & 4 days & Pneumonia & Haemophilus influenzae & 16 & 14.1 & 14.1 & 122 & 105 \\
\hline 15 & 2 & $12 \mathrm{~h}$ & Meningitis* & Haemophilus influenzae & 36 & 30.7 & 15.4 & 310 & 130 \\
\hline 16 & 45 & 7 days & Burn infection & Pseudomonas aeruginosa & 11 & 25.8 & 12.9 & 118 & 175 \\
\hline 17 & 4 & $12 \mathrm{~h}$ & Pyelonephritis & Pseudomonas aeruginosa & 22 & 44.5 & 11.1 & 159 & 230 \\
\hline 18 & 3 & 3 days & Pyelonephritis & Escherichia coli & 18 & 10.6 & 10.6 & 129 & 130 \\
\hline \multirow[t]{2}{*}{19} & 5 & 2 days & Peritonsilar abscess & Group A Streptococcus & & & & & \\
\hline & & & & Staphylococcus aureus & 24 & 6.5 & 6.5 & 141 & 165 \\
\hline 20 & 2 & 3 days & Pneumonia* & Haemophilus influenzae & 13 & 18.5 & 9.3 & 188 & 125 \\
\hline 21 & 14 & $3 \mathrm{yr}$ & Osteomyelitis & Pseudomonas aeruginosa & 16 & 11.2 & 11.2 & 107 & 110 \\
\hline 22 & 4 & 5 days & Pyelonephritis & Pseudomonas aeruginosa & 25 & 16.2 & 8.1 & 147 & 140 \\
\hline 23 & 14 & 7 days & Meningitis* & Staphylococcus aureus & 14 & 16.8 & 8.4 & 140 & 160 \\
\hline 24 & 6 & 1 day & Pyelonephritis & Pseudomonas aeruginosa & 18 & 37.0 & 9.3 & 171 & 190 \\
\hline 25 & 6 & 3 days & Pneumonia & Diplococcus pneumoniae & 31 & 18.1 & 9.2 & 258 & 200 \\
\hline
\end{tabular}

* The organism was isolated from blood cultures.

$\ddagger$ Leukocyte-rich plasma.

Cochrane, and Muller-Eberhard (5), and Baum, Mowat, and Kirk (6). Leukocyte-rich plasma was obtained by allawing the erythrocytes in $10 \mathrm{ml}$ of heparinized blood to settle over a 1 -h period. The concentration of polymorphonuclear leukocytes $(P M N)^{1}$ per milliliter of leukocyte-rich plasma was then determined by quantitative and differential cell counts. If the leukocyte-rich plasma contained between $2 \times 10^{8}$ and $16 \times 10^{8} \mathrm{PMN} / \mathrm{ml}, 0.1 \mathrm{ml}$ of the suspension was diluted to $0.4 \mathrm{ml}$ with tissue culture medium 199 (Microbiological Associates, Inc., Bethesda, Md.). The PMN in this suspension were then deposited on one side of a 5- $\mu \mathrm{m}$ pore size Millipore filter (Millipore Corp., Bedford, Mass.) utilizing a cytocentrifuge (Shandon Southern Instruments Inc., Sewickley, $\mathrm{Pa}$.). (If the concentration of PMN in the leukocyte-rich plasma was less than $2 \times 10^{8} / \mathrm{ml}$ or more than $16 \times 10^{8} / \mathrm{ml}$, an appropriate dilution of $1: 2,1: 8$, or $1: 16$ was made so that between $2 \times 10^{5}$ and $16 \times 10^{5}$ PMN in $0.4 \mathrm{ml}$ was deposited on each filter. When the number of PMN on the starting side of the filter was within this range, reliable leukotactic indexes were obtained and serial dilutions of a single leukocyte suspension gave indexes within $10 \%$ of each other.) The filters were immediately placed in a modified Boyden chamber (Neuro Probe, Inc., Bethesda, Md.), and a chemotactic stimulus was added to the attractant side. After incubation for $3 \mathrm{~h}$ at $37^{\circ} \mathrm{C}$, the filters were then removed, fixed in methanol, stained with hematoxylin, dried

${ }^{1}$ Abbreviations used in this paper: PMN, polymorphonuclear leukocytes. NBT, nitroblue tetrazolium. in ethanol, and cleared with xylene. The number of cells that had migrated completely through the filter within 10 random fields was determined by visual counting (using a $\times 10$ ocular, $\times 45$ objective, and $5 \times 5 \mathrm{~mm}$ photographic reticule). The slides were read blind in that the person counting the slides had no knowledge of the clinical or laboratory data on the individual being tested. A leukotactic index was calculated by dividing the number of PMN that had migrated completely through the filter within the reticule in 10 random fields by the total number of PMN $\left(\times 10^{6}\right)$ delivered to the starting side of the filter.

\section{Leukotactic Index}

$$
\begin{aligned}
& =\frac{\text { Number of PMN in } 10 \text { random fields }}{\text { Number of PMN }\left(\times 10^{6}\right) \text { in } 0.4 \mathrm{ml} \text { delivered }} \\
& \text { to starting side of filter }
\end{aligned}
$$

Using this method of calculating the index, only the number of PMN delivered to the starting side of the filter and the number moving through the filter are taken into account and thus, the assay appears to measure intrinsic leukotactic activity. As will be shown under results, there is no association between the number or percentage of PMN in the leukocyte-rich plasma or the total number of PMN delivered to the filter and the leukotactic index.

Most leukotactic assays were done in triplicate; occasionally small amounts of blood allowed only duplicate sampling. Using this method the standard deviation of triplicate samples is approximately $10 \%$ of the mean, 


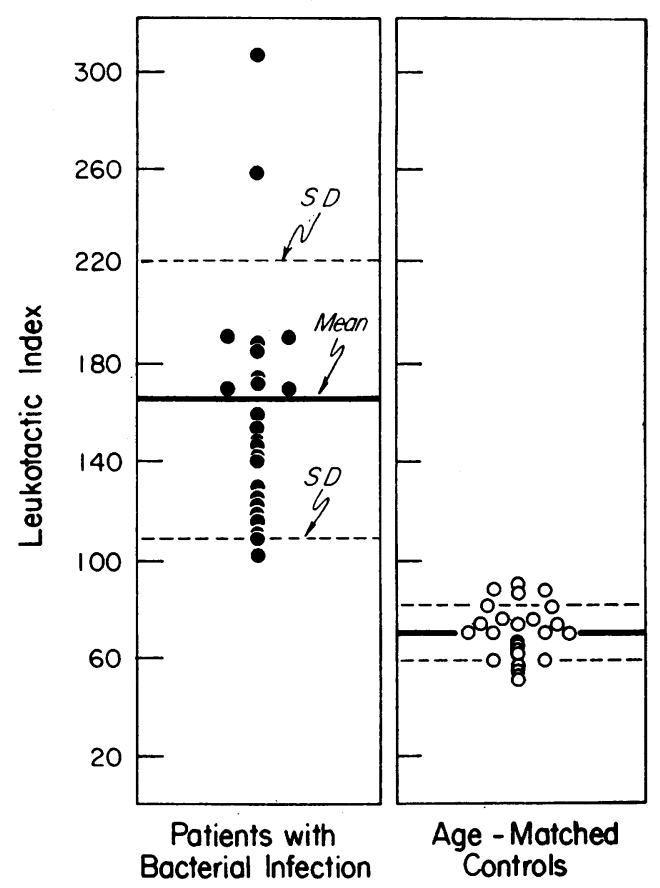

FIGURE 1 Leukotactic indexes of 25 patients with bacterial infection and 25 age-matched controls.

whereas the standard error of the mean was $6 \%$ when the same person was tested on three separate occasions. In testing the leukocytes of over 200 individuals, this method has proved to be sensitive and reproducible. In contrast to other systems for measuring leukotaxis, addition of settling agents such as dextran to the heparinized blood was not required, extensive handling of the cells was not done, and the presence of serum or albumin on the cell side of the chamber was not required to obtain optimal leukotaxis. To handle the leukocytes rapidly and with a minimal amount of trauma, we routinely have a small amount of the patient's plasma in the suspension deposited on the Millipore filters. The presence of the plasma is not necessary, however, since cells washed two to three times and resuspended in tissue culture medium 199 alone have normal leukotactic activity. The requirement of serum and albumin in the initial cell suspension for optimal leukotaxis, common to most other assay systems, is probably circumvented by depositing the cells on the filter with the cytocentrifuge. No association has been found between the leukotactic index and the age (except in neonates) or sex of the patient, the peripheral leukocyte count, the differential or the absolute number of neutrophils, or mononuclear cells.

Chemotactic factors. A bacterial chemotactic factor was prepared from a culture filtrate of Escherichia coli grown in medium 199 for $24 \mathrm{~h}$ at $37^{\circ} \mathrm{C}$ (7). After passage through a $0.22-\mu \mathrm{m}$ pore size Millipore filter, this bacterial chemotactic factor was frozen at $-70^{\circ} \mathrm{C}$ in $1-\mathrm{ml}$ ampules. Each day an ampule was thawed and diluted in medium 199 so that each milliliter of the solution contained $50 \mu 1$ of the factor. $2 \mathrm{ml}$ of this solution was added to the bottom or attractant side of the chemotactic chamber. Serums from controls and patients with bacterial infection were assayed for spontaneous complement-associated chemotactic activity and for activity after incubation with zymosan using methods described by Ward and co-workers (5).

Random mobility. Random mobility of leukocytes was determined by a modification of the method of McCall et al. (2). Glass capillary tubes were filled with a solution containing $1 \times 10^{7} \quad \mathrm{PMN} / \mathrm{ml}$. After centrifugation, the tubes were cut at the cell-fluid interface and placed in Sykes-Moore Chambers (Bellco Glass, Inc., Vineland, N. J.). After incubation for $4 \mathrm{~h}$, the leading edge of migrating granulocytes was mapped by projection microscopy and compared with a standard projected square centimeter to determine the absolute area of migration. Random mobility of PMN was also evaluated by determining the leukotactic index when no chemotactic stimulus was added to the attractant side of the modified Boyden chamber.

\section{Nitroblue tetrazolium dye reduction}

Spontaneous nitroblue tetrazolium (NBT) dye reduction by neutrophils was determined by a slight modification of the method of Park, Fikrig, and Smithwick (8). Approximately $0.1 \mathrm{ml}$ of heparinized blood was mixed with an equal volume of $0.1 \% \mathrm{NBT}$ solution and incubation was carried out for $30 \mathrm{~min}$ at $37^{\circ} \mathrm{C}$. Coverslips were then prepared, stained with $1 \%$ aqueous safranin for $3 \mathrm{~min}$, and the percentage of PMN that contained black deposits of formazan was determined visually.

\section{Serum complement BIC/BIA determinations}

Serum complement BIC/BIA determinations were measured by single radial diffusion in immunoplates (Hyland Div., Travenol Laboratories, Inc., Cost Mesa, Calif.).

\section{RESULTS}

Leukotaxis. The circulating neutrophils from patients with clinical and laboratory evidence of active bacterial infection had markedly increased leukotactic activity when compared with controls (Fig. 1). The mean leukotactic index of the patients $(165 \pm 56)$ was

\section{TABLE II}

Leukotactic Indexes of Febrile Patients with Viral Infections and Collagen Vascular Diseases

\begin{tabular}{lclc}
\hline \multicolumn{1}{c}{ Diagnosis } & $\begin{array}{c}\text { Leuko- } \\
\text { tactic } \\
\text { index }\end{array}$ & Diagnosis & $\begin{array}{r}\text { Leuko- } \\
\text { tactic } \\
\text { index }\end{array}$ \\
\hline Varicella & 42 & Ulcerative colitis & 77 \\
$\begin{array}{c}\text { Herpes virus } \\
\text { infection } \\
\text { (disseminated) }\end{array}$ & 40 & Rheumatoid arthritis & 56 \\
$\begin{array}{c}\text { Cytomegalovirus } \\
\text { infection } \\
\text { (disseminated) }\end{array}$ & 55 & Ulcerative colitis & 45 \\
$\begin{array}{c}\text { Herpes virus } \\
\text { encephalitis }\end{array}$ & 73 & $\begin{array}{c}\text { Fever of unknown } \\
\text { origin }\end{array}$ & \\
& & infection ruled out & 68 \\
\hline
\end{tabular}


more than twice that observed for the controls $(70 \pm 11$, $P<0.001)$ and none of the 25 patients with active infection had an index within the normal range (mean \pm 2 $\mathrm{SD}, 48-92$ ). There was no correlation between the type or severity of the infection and the leukotactic index, and no association was noted between the index and the presence or absence of bacteremia (Table I). The patient (no. 5) with multiple superficial staphylococcal skin abscesses and the patient (no. 4) with an infected decubitis ulcer had higher leukotactic indexes than the patient (no. 23) who had coagulase-positive staphylococcal meningitis or the patient (no. 3) with Haemophilus influenzae meningitis and sepsis. Leukotactic activity could not be correlated with the body temperature, antibiotic therapy, peripheral leukocyte count, differential or absolute number of PMN.

Several febrile patients with systemic viral infections and collagen vascular diseases have had leukotactic indexes within the normal range or slightly below normal (Table II).

$N B T$ reduction. A majority of the patients with active bacterial infection had an increased percentage of NBT-positive neutrophils (Fig. 2). Two of the patients, however, had less than $10 \%$ NBT-positive neutrophils. One of the patients (no. 8) had coagulasenegative staphylococcal endocarditis with multiple posi-

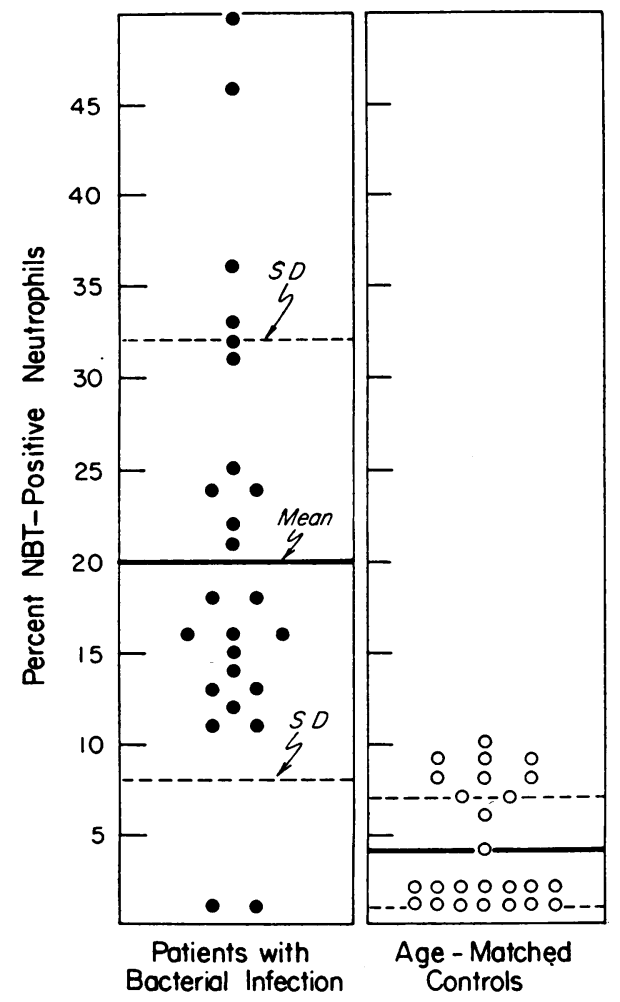

Figure 2 NBT dye reduction by neutrophils from 25 patients with bacterial infection and 25 age-matched controls.

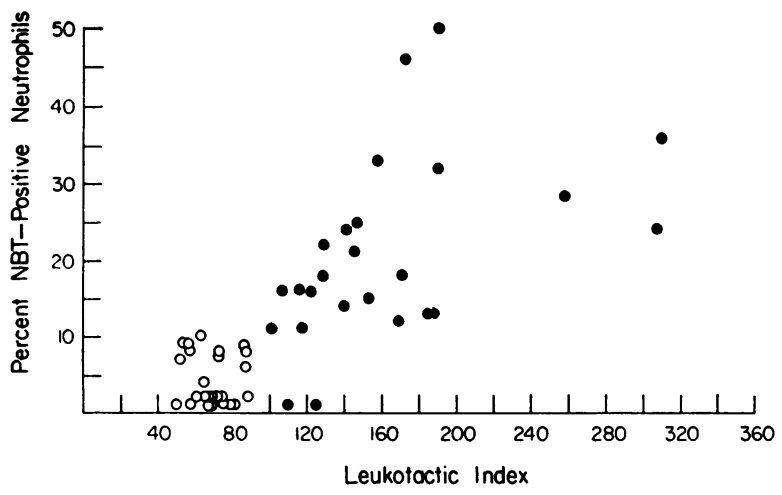

FIGURE 3 Leukotactic indexes and NBT reduction by neutrophils from 25 patients with bacterial infection and 25 age-matched controls. $\bigcirc$, controls; $\bullet$, patients with bacterial infection.

tive blood cultures but had an NBT of only $1 \%$. The leukotactic index of this patient was increased significantly, however. The other patient (no. 7) had coagulase-positive staphylococcal meningitis and only $1 \%$ NBT-positive neutrophils. His leukotactic index of 125 was also significantly increased.

Spontaneous NBT reduction by neutrophils and simultaneous leukotactic indexes are plotted in Fig. 3. A positive correlation exists between leukotactic activity and reduction of NBT dye by neutrophils ( $r=$ +7.5 , regression coefficient $=+3.9, \quad P<0.01$ ). As mentioned previously, however, two patients had low NBT and hyperactive leukotactic responses.

Random migration. The leukocytes of patients with active bacterial infection demonstrated normal random migration from capillary tubes. The mean area of migration at $4 \mathrm{~h}\left(7.5 \pm 2.2 \mathrm{~mm}^{2}\right)$ was not significantly different from that of controls $\left(9.0 \pm 3.6 \mathrm{~mm}^{2}\right)$. In addition, the mean leukotactic index of the patients with infection was not significantly different from that of controls when the chemotactic stimulus was not added to the attractant side of the modified Boyden chamber. No association was observed between leukotactic activity or NBT dye reduction and random migration as measured by the capillary tube or Boyden chamber technique.

Results of follow-up testing. 16 of the patients with bacterial infection were retested 7-14 days after initial testing. Three additional patients were also examined 21 days after initial testing (Fig. 4). The leukotactic index had decreased to within the normal range in 11 of the patients, all of whom were treated with appropriate antibiotics and who responded clinically and bacteriologically. A hyperactive leukotactic response continued, however, in five of the patients with persisting bacterial infection.

Patient N. M., who had draining staphylococcal osteomyelitis, was in the hospital for immunological eval- 


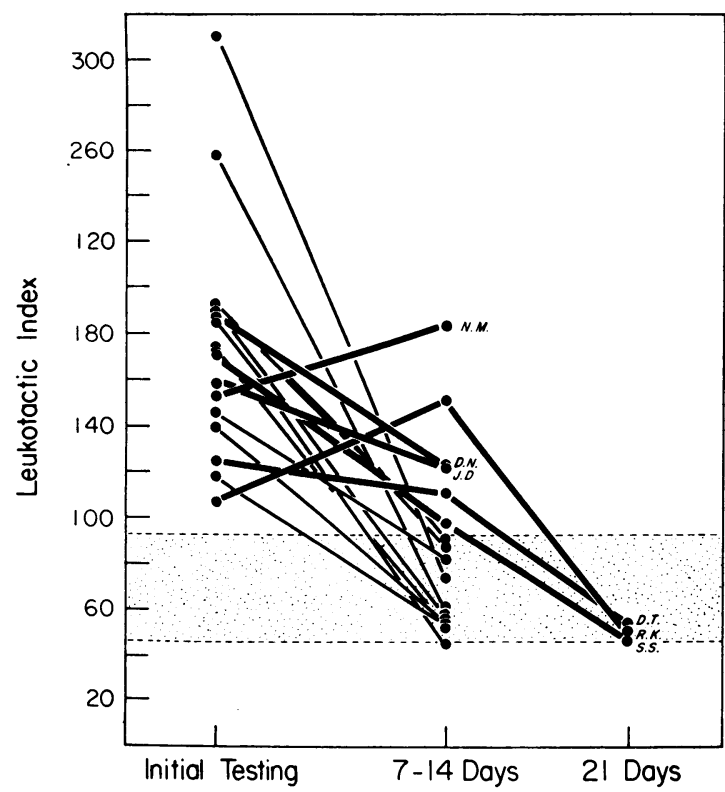

FIgURE 4 Serial leukotactic responses of neutrophils from patients with bacterial infection.

uation at the time of initial and follow-up leukocyte testing and was not on appropriate antistaphylococcal therapy.

Patient D. N. with pulmonary infiltrates on admission was treated conservatively with pulmonary therapy and no antibiotics. Cough and fever persisted, however, and the NBT rose from 13 to $25 \%$. The leukotactic index remained elevated at 123 . Lobar consolidation and a pleural effusion then developed which yielded $H$. influenzae on culture.

Patient J. D., who had obstructive uropathy, was treated for 10 days with gentamicin for a pseudomonas urinary tract infection. At the end of this time he continued to have low grade fever and later had evidence of persistent bacteriuria.

Patient D. T. had coagulase-positive staphylococcal meningitis which responded very slowly to parenteral methicillin and chloramphenicol therapy.

Patient S. S. had multiple staphylococcal skin abscesses. After 1 wk of intensive local therapy including the use of hexachlorophene containing soap and antibiotic ointments, the lesions had improved, but several continued to drain fluid which contained staphylococci. Oral cloxacillin therapy was administered for an additional week resulting in negative cultures and lowering of the leukotactic index.

Patient R. K. was admitted to the hospital with draining pseudomonas osteomyelitis. Gentamicin was administered for the first 7 days during which time he underwent surgery to remove as much of the infected bone as possible. The patient continued to have low grade fever and culture-positive drainage from a sinus tract over the area of bone involvement. Carbenicillin was added to the gentamicin and therapy continued for 2 more wk at which time the cultures were negative, the patient was afebrile, and the leukotactic activity of his circulating neutrophils had returned to normal.

Humoral chemotactic activity and complement BIC/ $B I A$ concentrations. Complement BIC/BIA concentrations in the patients with bacterial infection ranged from 110 to $230 \mathrm{mg} / 100 \mathrm{ml}$ with normal being 101-189 (Table I). Four of the patients had levels more than 2 $\mathrm{SD}$ above normal, but none had depressed concentrations even when sepsis was present.

Serum or plasma from the patients with bacterial infection and the controls demonstrated no significant inherent chemotactic activity for control neutrophils when added to the attractant side of the Boyden chamber. After activation of the complement sequence with zymosan, the chemotactic activity produced by the serum of patients with bacterial infections was not different from that of controls. (Table III).

Extensive attempts were made to stimulate leukotaxis or NBT dye reduction of control neutrophils with the serum or plasma from patients with bacterial infection. Leukocytes were washed, incubated in patients' serum or plasma for 30-60 min, and then tested for leukotactic activity and NBT reduction. No evidence of stimulation of either neutrophils function was detected. Repeated washing of the neutrophils from patients and controls did decrease leukotactic responsiveness somewhat, but the leukocytes of the patients remained hyperactive when compared with controls.

In-vitro stimulation of leukotaxis and NBT reduction. Leukocytes incubated for $10 \mathrm{~min}$ with $10 \mu \mathrm{g} / \mathrm{ml}$ of Salmonella enteritidis lipopolysaccharide endotoxin (Difco Laboratories, Detroit, Mich.), washed, and resuspended in tissue culture medium 199, showed significantly increased leukotactic activity and NBT reduction (Table IV). Incubation of leukocytes with the

TABLE III

Leukotactic Indexes of Control Neutrophils to Unactivated and Activated Serums from Patients with Bacterial. Infection and Age-Matched Controls

\begin{tabular}{cccc}
\hline & \multicolumn{2}{c}{ Mean leukotactic index* } \\
\cline { 3 - 4 } Serum & $\begin{array}{c}\text { Number } \\
\text { tested }\end{array}$ & $\begin{array}{c}\text { Unactivated } \\
\text { serum }\end{array}$ & $\begin{array}{c}\text { Zymosan- } \\
\text { activated } \\
\text { serum }\end{array}$ \\
\hline $\begin{array}{c}\text { Patients } \\
\text { Age-matched } \\
\text { controls }\end{array}$ & 25 & $11 \pm 2$ & $43 \pm 14$ \\
\hline
\end{tabular}

$*$ Mean \pm SD. 
bacterial chemotactic factor of serum activated with zymosan did not enhance leukotactic activity.

\section{DISCUSSION}

The present study of leukocyte function in 25 patients with active bacterial infection demonstrates that infection is capable of making circulating neutrophils more responsive to chemotactic stimulation. The hyperactive leukotactic response was present in all of the patients with proven bacterial infection but was absent in the small number of febrile patients that we studied with systemic viral infections and collagen vascular disease, Because of the small numbers of febrile patients, we do not feel that we can draw conclusions about leukotactic responsiveness in viral infections or collagen vascular diseases at the present time. Most of the patients with active bacterial infection had an increased percentage of NBT-positive neutrophils in addition to hyperactive leukotactic responses. Increased leukotactic activity was also demonstrated, however, in patients without an increased percentage of NBT-positive neutrophils or a peripheral leukocytosis. Thus, the hyperactive leukotactic response by circulating neutrophils may be an earlier and more sensitive reaction to bacterial invasion than the development of a peripheral leukocytosis or increased NBT dye reduction.

Bacterial factors or complement components produced or activated during infection may interact with circulating neutrophils altering their metabolic or physical properties so that increased leukotactic activity results. Ward and co-workers (5) observed increased clumping of neutrophils before initiation of leukotaxis, which suggests physical alteration of the cell membrane. More recently, we have found that cyclic nucleotides are important in the regulation of cell mobility, and specifically that substances which raise intracellular cyclic guanosine monophosphate, markedly stimulate leukotactic activity by neutrophils (9). We were unable, however, to demonstrate the presence of a stimulating factor in the serum or plasma of the patients with bacterial infection. If circulating factors are responsible for leukotactic hyperactivity, these may be rapidly inactivated by natural inhibitors in serum similar to those

\section{TABLE IV}

Leukotactic Response and NBT Dye Reduction by Control Neutrophils after Preincubation with $10 \mu \mathrm{g} / \mathrm{ml}$ of Salmonella enteritidis Endotoxin

\begin{tabular}{lcc}
\hline Preincubation solution & $\begin{array}{c}\text { NBT-positive } \\
\text { neutrophils }\end{array}$ & $\begin{array}{c}\text { Leukotactic } \\
\text { index }\end{array}$ \\
\hline Medium 199 & $\%$ & \\
Endotoxin & 6 & 69 \\
& 45 & 213 \\
\hline
\end{tabular}

described for anaphylotoxin (10). There was also no evidence that the complement system had been activated to produce circulating chemotactic factors and complement BIC/BIA levels were normal or elevated. Since none of our patients were in shock at the time of leukocyte testing, our findings agree with those of McCabe (11) who found depressed serum BIC/BIA levels only in patients with shock.

The hyperactive leukotactic response by circulating neutrophils in these patients with active bacterial infection was generally correlated with increased reduction of NBT dye. However, two of the patients with elevated leukotactic indexes had a low percentage of NBT-positive neutrophils. In addition, we have found that patients with chronic granulomatous disease, whose leukocytes fail to reduce NBT, have normal leukotactic activity. Thus leukotaxis does not appear to be dependent upon the metabolic events necessary for NBT dye reduction. It seems, however, that both of these leukocyte responses may be stimulated in a similar manner by bacterial infection.

Low doses of endotoxin are capable of increasing NBT reduction (12), and the phagocytic activity of neutrophils (13). We have also demonstrated that endotoxin is capable of enhancing leukotactic activity. Furthermore, work in experimental animals has shown that bacteremia or low doses of endotoxin are capable of enhancing local skin resistance to infection (14), and Perillie and co-workers have found an increased accumulation of neutrophils at the site of skin abrasion in patients with infection (4). In contrast, McCall and co-workers (2) found that neutrophils containing "toxic granulations" from patients with severe infection (38\% died) were less responsive in the leukotactic assay than neutrophils of controls or patients with infections without toxic granulation. We made no attempt to apply the subjective morphologic criteria used by $\mathrm{McCa}$ all to define toxic neutrophils in our patients. The patients we studied were not as severely ill as those studied by McCall and co-workers, however, and only 1 of the 25 died.

Mowat and Baum (6) using an in-vitro assay of leukotaxis found depressed responses by the neutrophils of 7 of 15 adult patients with bacterial infection. Only three of the seven patients had been tested within 1 wk of onset, however, and two of these were on antibiotic therapy. This might account for the differences in the two studies since appropriate antibiotic therapy decreases the leukotactic response. A difference in methodology might also aid in explaining the difference in our results and those of $\mathrm{McCall}$ and co-workers (2) and Mowat and Baum (3). In the studies of McCall et al. (2) plasmagel was used to sediment the erythrocytes. The cells in the leukocyte-rich plasma were then washed two or more times and the remaining eryth- 
rocytes were osmotically lysed with distilled water. The methods of Baum et al. (6), which are similar to the ones we used, differed in the addition of methylcellulose to sediment the erythrocytes. Although we have not added plasmagel to sediment erythrocytes, we have found that settling agents such as dextran, methylcellulose, or methylcellulose-Hypaque columns in association with extensive washing and handling of the cells depresses their leukotactic responses. This could reflect the removal of a plasma factor from the cells, but we have been unable to restore leukotactic responsiveness by the addition of fresh serum or plasma.

In the present study of patients with active bacterial infection tested before suppression of infection by antibiotic therapy, there was stimulation instead of suppression of leukotactic activity. This enhanced leukotactic response by circulating neutrophils could be detected early in infection and persisted until adequate therapy had eradicated the invading microorganisms. The importance of this response in localizing bacterial invasion of the body remains to be defined.

\section{ACKNOWLEDGMENTS}

We gratefully acknowledge Hattie Gray for technical assistance and the Pediatric housestaff of the University of Minnesota for assistance in collecting clinical specimens, and to Patti Lorenz for her secretarial assistance.

This study was supported by U. S. Public Health Service Grants AI 08821 and AI 06931, and the Department of Pediatrics Training Grant HD 00053-13. Part of these studies were conducted under the sponsorship of the commission on Streptococcal and Staphylococcal Disease of the Armed Forces Epidemiological Board with support by the Medical Research and Development Command U. S. Army under contract DADA-17-70-C-0082.

\section{REFERENCES}

1. Miles, A. A., E. M. Miles, and J. Burke. 1957. The value and duration of defense reactions of the skin to primary lodgement of bacteria. Br.J. Exp. Pathol. 38 : 79.
2. McCall, C. E., J. Caves, R. Cooper, and L. DeChatelet. 1971. Functional characteristics of human toxic neutrophils. J. Infect. Dis. 124: 68.

3. Mowat, A. G., and J. Baum. 1971. Polymorphonuclear leukocyte chemotaxis in patients with bacterial infections. Br. Med. J. 3 : 617 .

4. Perillie, P. E., J. P. Nolan, and S. C. Finch. 1962. Studies of the resistance to infection in diabetes mellitus: local exudative cellular responses. J. Lab. Clin. Med. 59 : 1008.

5. Ward, P. A., C. G. Cochrane, and H. J. Muller-Eberhard. 1965. The role of serum complement in chemotaxis of leukocytes in vitro. J. Exp. Med. 122: 327.

6. Baum, J., A. G. Mowat, and J. A. Kirk. 1971. A simplified method for the measurement of chemotaxis of polymorphonuclear leukocytes from human blood. $J$. Lab. Clin. Med. 77 : 501.

7. Ward, P. A., I. H. Lepow, and L. J. Newman. 1968. Bacterial factors chemotactic for polymorphonuclear leukocytes. Am. J. Pathol. 52: 725.

8. Park, B. H., S. M. Fikrig, and E. M. Smithwick. 1968. Infection and nitroblue-tetrazolium reduction by neutrophils. Lancet. $2: 532$.

9. Estensen, R. D., H. R. Hill, P. G. Quie, N. Hogan, and N. D. Goldberg. 1973. Cyclic GMP and cell movement. Nature (Lond.). 245: 458.

10. Müller-Eberhard, H. J., E. H. Vallota, O. Gotze, and T. S. Zimmerman. 1972. Mediators of the inflammatory response-complement. In Inflammation, Mechanisms and Control. I. H. Lepow and P. A. Ward, editors. Academic Press, Inc., New York. 1st edition. 83.

11. McCabe, W. R. 1973. Serum complement levels in bacteremia due to gram-negative organisms. N. Engl. J. Med. $288: 21$.

12. Matula, G., and R. Y. Patterson. 1971. Spontaneous in vitro reduction of nitroblue tetrazolium by neutrophils of adult patients with bacterial infection. N. Engl. J. Med. $285: 311$.

13. Cohn, Z. A., and S. I. Morse. 1960. Functional and metabolic properties of polymorphonuclear leukocytes. II. The influence of a lipopolysaccharide endotoxin. $J$. Exp. Med. $111: 689$.

14. Miles, A. A. 1964. The acute reactions of injury as an antimicrobial defense. In International Symposium on Injury, Inflammation and Immunity. L. Thomas and J. W. Uhr, editors. Williams \& Wilkins Co., Baltimore. 1st edition. 162 . 